\title{
PELATIHAN TRIK PEMBUATAN KARYA TULIS BERBENTUK PTK DI MA AL-HIDAYAH
}

\author{
Rica Wijayanti*, Didik Hermanto, Buaddin Hasan \\ Pendidikan Matematika, STKIP PGRI Bangkalan \\ email: ricawijayanti@stkippgri-bkl.ac.id
}

\begin{abstract}
The training in making tricks in the form of Classroom Action Research aims to help overcome the problems of the teachers in MA Al-Hidayah in the case of the difficulty of making PTK-shaped tuis work. In addition, this training can also increase knowledge for teachers so that the level of professionalism of teachers in MA Al-Hidayah is higher. The method used in this training is to use lecture, discussion, direct demonstration, and mentoring methods The method of reflection and discussion is applied when delivering the basic principles of implementing classroom action research; the demonstration method is applied when delivering material for innovative learning models and making instructional media; the guidance method is applied during the process of making a paperwork in the form of a PTK. The instrument used to see the success of the training program was the participant's questionnaire response sheet. Based on the results of the questionnaire distributed, it was found that each training conducted $\geq 75 \%$ of the trainees had a very good understanding of the material delivered during the training. In addition, the final results of this training are in the form of written product in the form of CAR as many as 20 works created by the trainees themselves.
\end{abstract}

Keywords: Training, Tricks of Writing, and PTK

\begin{abstract}
Abstrak
Pelatihan trik pembuatan karya tulis berbentuk Penelitian Tindakan Kelas ini bertujuan untuk membantu mengatasi permasalahan guru-guru di MA Al-Hidayah dalam hal kesulitan pembuatan karya tuis berbentuk PTK. Selain itu, pelatihan ini juga dapat menambah pengetahuan bagi para guru sehingga tingkat profesionalisme guru di MA Al-Hidayah semakin tinggi. Metode yang digunakan dalam pelatihan ini adalah menggunakan metode ceramah, diskusi, peragaan langsung, dan pembimbingan Metode ceramah dan diskusi diterapkan saat menyampaikan materi prinsip dasar pelaksanaan penelitian tindakan kelas; metode peragaan diterapkan saat menyampaikan materi modelmodel pembelajaran yang inovatif dan pembuatan media pembelajaran; metode pembimbingan diterapkan saat proses pembuatan pembuatan karya tulis berbentuk PTK. Instrumen yang digunakan untuk melihat keberhasilan program pelatihan ini adalah lembar angket respon peserta pelatihan. Berdasarkan hasil angket yang dibagikan diperoleh hasil bahwa setiap pelatihan yang dilakukan $\geq$ 75\% peserta pelatihan telah sangat paham terhadap materi yang disampaikan saat pelatihan berlangsung. Selain itu, hasil akhir dari pelatihan ini yaitu berupa produk karya tulis berbentuk PTK sebanyak 20 karya yang dibuat sendiri oleh para peserta pelatihan.
\end{abstract}

Kata Kunci : Pelatihan, Trik Pembuatan karya Tulis, dan PTK 


\section{PENDAHULUAN}

Sekolah-sekolah yang berada di kawasan kota Bangkalan sangat banyak baik negeri maupun swasta. Salah satu sekolah swasta yang berbentuk pondokan di kota Bangkalan adalah MA AL HIDAYAH. Sekolah ini memiliki tempat yang stategis karena mudah dijangkau oleh siapa saja. Selain itu, di sekolah yang sekaligus pondok pesantren ini juga memiliki sarana berupa asrama baik asrama putra maupun asrama putri.

Banyaknya siswa disana membuat sekolah tersebut harus mencari banyak guru dengan keprofesionalan yang cukup tinggi. Selain itu, sekolah ini juga mempuntai akreditasi A yang harus tetap dipertahankan. Oleh karena itu, sekolah terus berusaha untuk mewujudkan impian dari orang tua siswa yang menginginkan anak mereka mendapatkan pendidikan yang berkualitas baik berupa pendidikan agama maupun ilmu pengetahuan lainnya.

Perubahan kurikulum yang terjadi dari kurikulum KTSP menjadi kurikulum 2013 cukup membuat guru-guru di sekolah tersebut mengalami banyak permasalahan khususnya dalam bidang pengajaran. Proses pembelajaran yang harus berupa dari yang awalnya teacher center menjadi student center. Untuk membuat siswa terbiasa dengan situasi perubahan kurikulum yang baru ini guru-guru harus banyak melakukan sebuah penelitian tindakan kelas. Hal ini disebabkan guru harus mencoba beberapa model pembelajaran dan media pembelajaran yang baru sehingga cocok dengan keinginan pemerintah yang menginginkan siswa untuk aktif dalam setiap proses pembelajaran.

Namun, permasalahan yang terjadi di sekolah tersebut adalah minimnya pengetahuan guru tentang penelitian tindakan kelas. Akibatnya, permasalahan yang terjadi selama proses pembelajaran tidak cepat teratasi. Oleh karena itu, kami akan mengadakan pelatihan trik pembuatan karya tulis dalam bentuk PTK di MA Al-Hidayah. Penelitian Tindakan
Kelas menurut (Arikunto, 2006) adalah suatu pecermatan terhadap proses pembelajaran berupa sebuah tindakan yang sengaja dilakukan dengan tujuan untu memperbaiki proses pembelajaran. Mengingat pentingnya PTK bagi seorang guru, maka setiap guru harus dibekali ilmu pengetahuan tentang trik pembuatan karya tulis pembuatan PTK.

Pelatihan tentang pembuatan PTK sudah pernah dilakukan sebelumnya oleh (Suwarno, 2016), dari hasil pelatihan tersebut menunjukkan bahwa selain profesionlisme guru semakin meningkat, proses pembelajaran juga lebih berjalan dengan kondusif. Akibatnya, hasil belajar siswa juga mengalami peningkatan. Berdasarkan hasil pelatihan yang pernah diadakan sebelumnya oleh pengabdi lain di tempat yang berbeda, maka kami yakin bahwa pelatihan trik pembuatan karya tulis pembuatan PTK akan menjadi solusi paling tepat untuk mengatasi permasalahan di MA Al-Hidayah. Pelatihan yang akan kami lakukan dibagi menjadi 4 tahap yaitu tahap pertama pelatihan tentang prinsip dasar pelaksanaan penelitian tindakan kelas. Pelatihan kedua tentang model-model pembelajaran yang inovatif. Pelatihan ketiga tentang pembuatan media pembelajaran. Pelatihan keempat tentang pembuatan karya tulis dalam bentuk penelitian tindakan kelas.

\section{METODE PENGABDIAN}

Metode yang ditawarkan oleh kami selaku pelaksana program pengabdian kepada masyarakat ini adalah dengan memberikan beberapa pelatihan tentang penelitian tindakan kelas. Pelatihan ini akan dilakukan beberapa kali dengan beberapa topik yaitu (1) Prinsip dasar pelaksanaan penelitian tindakan kelas; (2) Model-model pembelajaran yang inovatif; (3) Pembuatan media pembelajaran; (4) Pelaksanaan penelitian tindakan kelas; (4).Pembuatan karya tulis dalam bentuk penelitian tindakan kelas. Pelatihan setiap 
topik akan diikuti dengan proses pembimbingan dimana guru-guru di akhir program pengabdian masyarakat ini minimal sudah memiliki karya tulis dalam bentuk penelitian tindakan kelas yang mereka buat sendiri sehingga dapat digunakan sebagai kenaikan jenjang karier dan persiapan akreditasi oleh sekolah.

Selain itu, metode yang kami pilih ini bertujuan agar permasalahan siswa yang terjadi dalam proses pembelajaran cepat teratasi dengan solusi yang tepat sehingga kualitas mutu lulusan di MA AL-Hidayah setara dengan nilai akreditasinya yang A. Proses pembimbingan tidak hanya dilakukan saat kami mendatangi mitra melainkan mitra juga dapat menghubungi kami ketika mengalami kesulitan baik melalui media komunikasi maupun mendatangi kami secara langsung.

Melalui metode yang kami tawarkan diatas, maka rencana kegiatan dari program pengabdian kepada masyarakat ini adalah sebagai berikut:

a. Tahap Persiapan

Sebelum program pengabdian kepada masyarakat ini dilakukan ada beberapa hal yang harus kami persiapkan diantaranya yaitu (1) mencari referensi tentang penelitian tindakan kelas; (2) mengadakan observasi awal ke tempat mitra untuk melihat permasalahan yang terjadi di sekolah tersebut; (3) mempersiapkan segala sesuatu yang dibutuhkan saat pelaksanaan kegiatan.

b. Tahap Pelaksanaan

Pelaksanaan kegiatan program ini adalah dalam bentuk pelatihan dan pembimbingan tentang penelitian tindakan kelas. Pada tahap pelaksanaan ini akan diikuti oleh seluruh guru-guru di sekolah mitra. Tahap ini akan dilakukan kurang lebih selama 2 bulan. Selama waktu pelaksanaan program pengabdian guru-guru akan dibimbing hingga mengahsilkan sebuah produk berupa karya tulis ilmiah dalam bentuk penelitian tindakan kelas. Hal ini dikarenakan harapannya setelah berakhirnya program pengabdian masyarakat ini guru-guru disana dapat melakukan penelitian dan pembuatan karya tulis PTK secara mandiri.

c. Tahap Akhir

Tahap akhir pada program pengabdian kepada masyarakat ini adalah pembuatan laporan akhir dan artikel ilmiah yang akan dipublikasikan pada jurnal nasional atau prosiding ilmiah

Setelah kegiatan pengabdian kepada masyarakat ini selesai kami lakukan,, maka kami akakan melakukan evaluasi terhadapa keberhasilan program yang kami jalankan. Jika program yang kami jalankan masih mengalami kekurangan, maka kami akan mengadakan program lanjutan untuk memperbaiki kekurangan tersebut. Namun, Jika program ini mengalami keberhasilan, maka kami akan mengajak guru-guru yang sudah mahir dalam pembuatan karya tulis penelitian tindakan kelas untuk membentuk suatu komunitas sehingga dapat menjadi tutor bagi guru-guru di sekolah lain.

\section{HASIL DAN PEMBAHASAN}

Hasil dari program pengabdian kepada masyarakat dengan judul pelatihan trik pembuatan karya tulis berbentuk PTK yang dilaksanakan di MA Al-Hidayah dengan dihadiri 20 orang guru adalah sebagai berikut.

1. Kegiatan pelatihan pertama dalam program ini adalah pemberian pelatihan kepada guru-guru di MA AlHidayah tentang prinsip dasar PTK. Pada kegiatan ini seluruh peserta menikmati sajian materi dari kami. Cara penyajian materi yang kami lakukan adalah membagikan hand out dan menggunakan bantuan media power point. Setelah materi selesai disajikan, kemudian kami memberikan angket respon kepada para peserta untuk mengetahui respon 
peserta selama mengikuti pelatihan pertama. Berikut ini adalah hasil respon dari para peserta pada pelatihan pertama.

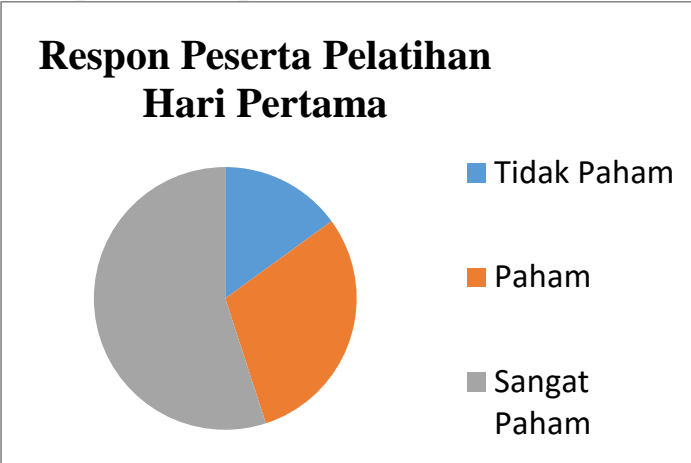

Gambar 1. Respon peserta pelatihan hari pertama

2. Kegiatan pelatihan kedua dalam program ini adalah pemberian pelatihan kepada guru-guru di MA AlHidayah tentang model-model pembelajaran yang inovatif. Pada kegiatan kedua penyaji menggunakan hand out dan peragaan langsung tentang penerapan model-model pembelajaran yang inovatif. Pelatihan kedua ini dilakukan agar dalam membuat karya tulis PTK guru-gur tidak bingung mencari model-model pembelajaran yang akan dijadikan sebagai solusi dari permasalahan yang ada. Pada pelatihan kedua ini penyaji juga memberikan angket respon pada seluruh peserta pelatihan. Berikut ini adalah hasil respon dari para peserta.

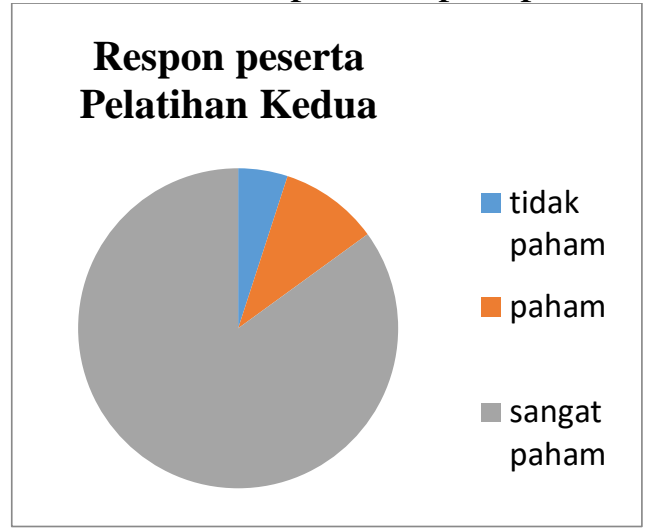

Gambar 2. Respon peserta pelatihan hari kedua

3. Kegiatan pelatihan ketiga dalam program ini adalah pemberian pelatihan kepada guru-guru di MA AlHidayah tentang pembuatan media pembelajaran. Pelatihan ini merupakan bagian dari bekal sebelum diadakan pelatihan tentang pembuatan karya tulis dalam bentuk PTK. Pelatihan ini berfungsi agar guru-guru bisa mengetahui berbagai jenis media pembelajaran untuk dijadikan solusi dari permasalahan tindakan kelas. Setelah pelatihan ketiga selesai dilaksanakan, kemudian penyaji materi memberikan angket respon untuk para peserta pelatihan. Berikut ini adalah hasil respon dari para peserta.

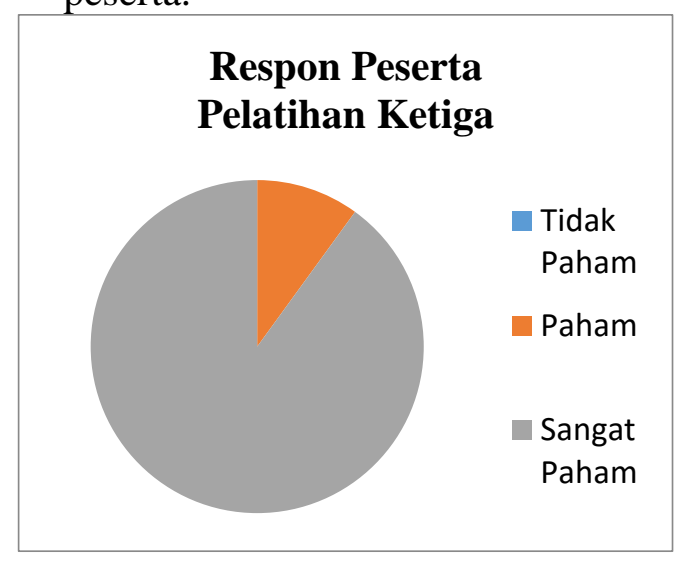

Gambar 3. Respon peserta pelatihan hari ketiga

4. Kegiatan pelatihan keempat dalam program ini adalah pemberian pelatihan kepada guru-guru di MA AlHidayah tentang pembuatan karya tulis dalam bentuk PTK. Pada kegiatan pelatihan ini penyaji memberikan materi cara pembuatan karya tulis dalam bentuk PTK kepada para peserta, mulai dari kegiatan observasi awal untuk melihat permasalahan yang terjadi sampai pada pemberian solusi terhadap permasalahan tersebut. Setelah pemaparan materi selesai kemudian penyaji meminta seluruh para peserta untuk membuat karya tulis dalam bentuk PTK sesuai dengan permasalahan yang dialami ketika mereka mengadakan proses pembelajaran di kelas. Selama proses 
pembuatan karya tulis PTK, penyaji memberikan fasilitas pembimbingan yang dapat dilakukan selama kurang lebih satu bulan baik komunikasi secara langsung maupun melalui media sosial. Kegiatan pelatihan ini berakhir dengan menghasilkan 20 karya ilmiah berbentuk PTK yang dapat digunakan oleh para peserta untuk pengajuan kenaikan pangkat. Selain itu, adanya pelatihan ini juga menghasilkan sebuah perbaikan dalam proses pembelajaran sesuai bidang ilmu masing-masing peserta pelatihan.

\section{SIMPULAN}

Setelah pelatihan trik pembuatan karya tulis berbentuk PTK ini selesai dilaksanakan dapat disimpulkan beberapa hal yaitu;

a. Guru-guru yang menjadi peserta pelatihan mendapatkan pengetahuan yang banyak tentang PTK.

b. Pembuatan karya tulis berbentuk PTK sudah bukan menjadi masalah yang berat bagi guru-guru di MA Al-Hidayah

c. Setiap peserta pelatihan sudah menghasilkan masing-masing sebuah karya tulis berbentuk PTK sesuai dengan bidang keahlian masing-masing

d. Permasalahan dalam proses pembelajaran yang dialami oleh guru bidang studi di MA Al-Hidayah sudah teratasi, hal ini terbukti hasil belajar siswa setelah diterapkannya PTK mengalami peningkatan.

\section{UCAPAN TERIMA KASIH}

Kami mengucapkan terima kasih yang sebesar-besarnya kepada:

a. LPPM STKIP PGRI Bangkalan sebagai pemberi bantuan dana pengabdian kepada masyarakat.

b. Dosen-dosen Program Studi Pendidikan Matematika STKIP PGRI Bangkalan yang memotivasi dan memberikan bantuan saat pelaksanaan program pengabdian kepada masyarakat. c. Kepala sekolah MA Al-Hidayah yang telah memberikan waktu dan fasilitas saat pelaksanaan program pengabdian kepada masyarakat.

d. Seluruh peserta pelatihan yang meluangkan waktu sehingga program pengabdian kepada masyarakat ini dapat berjalan dengan lancar.

\section{DAFTAR PUSTAKA}

[1]. Arikunto, S. (2006). Prosedur Penelitian Suatu Pendekatan Praktik. Jakarta: Rineka Cipta.

[2]. Arikunto, Suharsimi, dkk. 2009. Penelitian Tindakan Kelas. Jakarta: PT Bumi Aksara.

[3]. Depdikbud. 1999. Penelitian Tindakan Kelas. Jakarta: Depdikbud, Ditjen Dikdasmen.

[4]. Suwarno, D. S. (2016). PTK Dengan Pembelajaran Berbasis Kearifan Lokal dan Penulisan Artikel Ilmiah Di SD Kalisume banyumas. Khazanah Pendidikan, Jurnal Ilmiah Kependidikan , 1-11.

[5]. Jalil, Jasman. 2014. Penelitian Tindakan Kelas. Jakarta: Prestasi Pustaka. 